\title{
Clinical significance of the uPA system in gastric cancer with peritoneal metastasis
}

\author{
Youcheng Ding ${ }^{1}$, Hui Zhang ${ }^{1}$, Mingan Zhong ${ }^{1}$, Zhuqing Zhou', Zhixiang Zhuang ${ }^{1}$, Hua Yin' ${ }^{1}$ Xujing Wang ${ }^{1}$ \\ and Zhenggang Zhu ${ }^{2 *}$
}

\begin{abstract}
Background: It has been demonstrated that urokinase-type plasminogen activator (UPA) is involved in tumor cell metastasis by degrading the extracellular matrix. However, there is little direct evidence of clinical uPA system expression in peritoneal metastatic tissues of gastric cancer. The objective of this study was to investigate uPA system expression in peritoneal tissues of peritoneal and nonperitoneal metastasis patients, and to explore the diagnostic value of the UPA system.

Methods: Expressions of UPA, UPAR, and PAI-1 were measured by semi-quantitative RT-PCR and ELISA. UPA activity was detected using a uPA activity kit.

Results: There was no significant difference in UPA, UPAR, and PAl-1 expression in two types of peritoneal tissue in seven patients with peritoneal metastasis. However, UPA, UPAR, and PAI-1 expressions in peritoneal metastatic lesions were significantly higher than those in normal peritoneal tissues of 24 nonperitoneal metastasis patients $(P<0.05)$. Moreover, no statistical discrepancy of uPA activity was observed in various different tissues.

Conclusions: The expression of the UPA system positively correlates with peritoneal metastasis of gastric cancer. This expression difference in peritoneal or nonperitoneal metastasis patients may provide a reference for diagnosis of peritoneal metastasis.
\end{abstract}

Keywords: Gastric cancer, ELISA, Peritoneal metastasis, RT-PCR, UPA system

\section{Background}

Although the incidence and mortality of gastric cancer have decreased in China over the last few decades, gastric cancer is still a big burden of the local health program [1]. Importantly, the recurrence of gastric cancer occurs even after potentially curative resection, most frequently in the form of peritoneal metastasis [2]. Thus, there is an urgent need to develop effective early diagnosis strategies for peritoneal metastasis of gastric cancer.

Cancer invasion and metastasis are multifactorial processes [3] and an essential step involves consecutive destruction and reconstitution of the extracellular matrix and basement membranes, which in turn requires the participation of several proteolytic enzyme systems, such as serine proteases and metalloproteases [4]. Urokinase-

\footnotetext{
* Correspondence: zhenggang_zhu132@hotmail.com

${ }^{2}$ Department of Gastroenterology, Ruijin Hospital, Shanghai Jiao Tong University School of Medicine, 197 Ruijin Road II, Shanghai 200025, China Full list of author information is available at the end of the article
}

type plasminogen activator ( $\mathrm{UPA}$ ) is one of the serine proteinases and it binds to its receptor, the uPA receptor (UPAR) on the surface of the tumor cell. After activation, cell-bound uPA is capable of converting plasminogen into plasmin, which is then able to degrade several components of the extracellular matrix [5]. The action of the uPA-uPAR complex on plasminogen can be controlled by the protease inhibitors PAI [6,7]. Thus, a balanced production of cellular and pericellular uPA, uPAR, and PAI-1 is the prerequisite for efficient focal proteolysis, cell adhesion, and migration, and hence, tumor cell invasion and metastasis $[8,9]$.

It has been observed that the uPA system is well correlated with gastric cancers, by measuring the expression level of uPA, uPAR, and PAI-1 in gastric cancer and normal mucosal tissue and analyzing their correlation with various clinical pathological characteristics. For example, Plebani et al. [10] determined uPAR, uPA, and PAI-1 levels using ELISA in gastric cancer and normal samples 
from 20 patients with gastric cancer undergoing surgery. UPAR expression level is significantly higher in gastric cancer, and low levels of uPAR are associated with a better survival. Taniguchi et al. [11] studied the relationship between the expression of UPAR and clinicopathologic parameters using immunohistochemical analysis from 102 primary gastric carcinomas. UPAR immunoreactivity was observed in 38 cases out of 102 (37\%). In addition, the expressions of uPA, uPAR, and PAI-1 are significantly correlated with various clinicopathological factors: tumor size, depth of tumor invasion, differentiation, lymph node metastasis [12-15], and peritoneum metastasis $[16,17]$.

However, there has been very little direct evidence to demonstrate the clinical significance of the uPA system in distinguishing peritoneal metastatic from normal peritoneal tissues in gastric cancer. Compared with the regular distribution and arrangement of lymph nodes, peritoneal tissue has a larger area, occupying the whole peritoneal cavity, thus entailing more randomness and unpredictability in cell peritoneal metastasis in gastric cancer. Thus, the objective of this study was to investigate further the expression difference of the uPA system between peritoneal metastatic tissues and normal peritoneal tissues of gastric cancer and to confirm the diagnosis significance of the uPA system by combining these results with clinical data.

\section{Methods}

\section{Clinical sample}

We assessed 31 patients (21 men, 10 women) with a diagnosis of gastric cancer, who had been admitted to our department between July 2010 and December 2010. Their average age was 62.58 years (range, 23 to 85 ). The patients were diagnosed with gastric cancer based on the preoperative or postoperative pathological analysis. Among them, 7 patients had peritoneal metastasis (pathological type: 1 case of moderately differentiated tubular adenocarcinoma, 1 case of grade II to III adenocarcinoma, 3 cases of poorly differentiated adenocarcinoma, and 3 cases of poorly differentiated adenocarcinoma combined with signet ring cell carcinoma), while 24 patients had nonperitoneal metastasis (pathological type: 3 cases of moderately differentiated tubular adenocarcinoma, 3 cases of grade II adenocarcinoma, 2 cases of grade II to III adenocarcinoma, 9 cases of poorly differentiated adenocarcinoma, 3 cases of signet ring cell carcinoma, 1 case of mucinous carcinoma, 1 case of grade II adenocarcinoma combined with signet ring cell carcinoma, 1 case of grade III adenocarcinoma combined with signet ring cell carcinoma, and 1 case of grade II adenocarcinoma combined with mucinous carcinoma).

In the patients with peritoneal metastasis, we excised the peritoneal metastasis lesions, as well as a small amount of omentum majus, pelveoperitoneum, and diaphragmatic peritoneum without peritoneal metastasis. In the patients with nonperitoneal metastasis, a few resections of the omentum majus, pelveoperitoneum, and diaphragmatic peritoneum were also performed. The collected samples were stored at $-80^{\circ} \mathrm{C}$ for further analysis.

All patients were alive at the end of the research, and our study was approved by the ethics committee of Shanghai East Hospital, affiliated to Tong Ji University.

\section{Cell culture}

Cells from a peritoneal mesothelial cell line (HMrSV5) were maintained in DMEM (Sigma, St. Louis, USA) supplemented with $10 \%$ fetal bovine serum. The cells were subcultured almost every day by 1:4 or 1:5 dilution in culture flasks at $37^{\circ} \mathrm{C}$ under an atmosphere of $5 \% \mathrm{CO}_{2}$.

\section{Total RNA extraction and CDNA synthesis}

Total RNA was isolated by cell precipitation using an RNeasy $^{\text {Tax }}$ RNA extraction kit following the manufacturer's instructions (Qiagen, Valencia, USA). The RNA purity and concentration were determined by spectrophotometric absorbance at 260 and $280 \mathrm{~nm}$, respectively. Reverse transcription was performed on $1 \mu \mathrm{g}$ of total RNA using oligo (dT) primers and AMV reverse transcriptase (Promega, Madison, USA). The $20 \mu \mathrm{l} \mathrm{PCR} \mathrm{reaction} \mathrm{mixture} \mathrm{contained}$

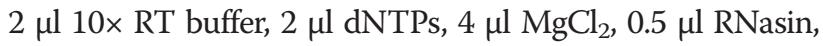
$1 \mu \mathrm{l}$ oligo $(\mathrm{dT})_{18}, 0.75 \mu \mathrm{l}$ reverse transcriptase, and $1 \mu \mathrm{g}$ RNA. The PCR condition was $70^{\circ} \mathrm{C}$ for $10 \mathrm{~min}, 42^{\circ} \mathrm{C}$ for 15 min, and $99^{\circ} \mathrm{C}$ for $5 \mathrm{~min}$, after which the cDNA was stored at $4^{\circ} \mathrm{C}$ (within 3 months).

\section{Semi-quantitative RT-PCR}

The gene expression levels of uPA, uPAR, and PAI-1 were determined by comparison with $\beta$-actin gene or glyceraldehyde-3-phosphate dehydrogenase (GAPDH). The $25 \mu \mathrm{l}$ RT-PCR reaction mixture contained $1 \mu \mathrm{l}$ cDNA, sense and anti-sense primers (each $0.25 \mu \mathrm{l}$ ), 2.5 $\mu \mathrm{l} 10 \times$ PCR buffer, $2 \mu \mathrm{l} 25 \% \mathrm{MgCl}_{2}, 0.5 \mu \mathrm{l}$ Taq polymerase, $1 \mu \mathrm{l}$ dNTP, and $17.5 \mu \mathrm{l}$ Rnase-free $\mathrm{H}_{2} \mathrm{O}$. Nested PCR was used for the amplification of carcinoembryonic antigen (CEA) with $1 \mu \mathrm{l}$ of first PCR product used for the second PCR template. The amplification conditions were: (i) initial denaturation at $95^{\circ} \mathrm{C}$ for $5 \mathrm{~min}$; (ii) 30 cycles of denaturation at $94^{\circ} \mathrm{C}$ for $1 \mathrm{~min}$; (iii) annealing at $56^{\circ} \mathrm{C}$ for $30 \mathrm{~s}$ for $\mathrm{uPA}, 60^{\circ} \mathrm{C}$ for $1 \mathrm{~min}$ for uPAR, $55^{\circ} \mathrm{C}$ for $1 \mathrm{~min}$ for PAI-1, or $72^{\circ} \mathrm{C}$ for $2.5 \mathrm{~min}$ for CEA; and (iv) extension at $72^{\circ} \mathrm{C}$ for $1 \mathrm{~min}$ or $2.5 \mathrm{~min}$. The PCR primers used were as follows: for uPA, A, 5'-AGAA TTCACCACCATCGA GA-3' and B, 5'-ATCAGCTT CACAACAGTCA T-3'; for uPAR, A, 5'-ACA GGAG CTGCCCTCGCGAC-3' and B, 5'-GAGGGGGATTT CAGGTTT AGG-3'; for PAI-1, A, 5'-CTTTGGTGAA GGGTCTGC-3' and B, 5'-CTC CACCTCTGAAAAGT CC-3'; for CEA, A, 5'-TCTGGAACTTCTCCTGGTCT 
CAGCTGG-3', B, 5' -TGTAGCTGTTGCAAATGCTTT AAGGAAGAAGC-3', and C, 5'-GGGCCACTGTCGG CATCATG ATTGG-3'; for $\beta$-actin, A, 5'-TTGAA GGTAGTTTC GGGAAT-3' and B, 5'-GAA AATCTG GCACCACAC CTT-3'; for GAPDH, A, 5'-GAAGGT GAAGGCGGAGT C-3' and B, 5'-GAAGATGGTGA TGGGATTTC-3'. The A and B primers of CEA were used for the first PCR, while the $\mathrm{B}$ and $\mathrm{C}$ primers were used for the second amplification. The amplification product was $474 \mathrm{bp}, 1046 \mathrm{bp}, 409 \mathrm{bp}, 131 \mathrm{bp}, 591 \mathrm{bp}$, and $230 \mathrm{bp}$, respectively.

\section{Quantitative ELISA analysis}

Tris-buffered saline ( $\mathrm{pH} 8.5,1.8 \mathrm{ml}$ ) was added to frozen tissues (100 to $300 \mathrm{mg}$ ) and homogenization was performed in an ice-bath. Subsequently, $0.2 \mathrm{ml} 10 \%$ Trixon X-100 was added to ensure a final concentration of $1 \%$ Trixon X-100 in the homogenate. The homogenate was shaken for $16 \mathrm{~h}$ and then centrifuged in a refrigerated centrifuge at $4^{\circ} \mathrm{C}$ for $1 \mathrm{~h}$ at $100,000 \mathrm{~g}$. The supernatant was transferred to a new tube and the protein concentration was determined by a bicinchoninic acid assay. Concentrations of uPA, UPAR, and PAI-1 antigen were determined using ELISA kits according to the manufacturers' instructions (American Diagnostica, Greenwich, USA). The reaction was stopped by the addition of $50 \mu \mathrm{H}_{2} \mathrm{SO}_{4}$, and the absorption was measured at $450 \mathrm{~nm}$ on an ELISA plate reader (EL312e microplate reader, Bio-Tek Instruments, Winooski, USA). Values of uPA, uPAR, and PAI-1 antigen were expressed as $\mathrm{ng} / \mathrm{mg}$ protein.

\section{uPA activity assay}

uPA activity was measured using an uPA activity assay kit (Chemicon). Briefly, tissue protein was mixed with assay buffer and incubated with a chromogenic substrate in 96 -well plates at $37^{\circ} \mathrm{C}$ for 2 to $24 \mathrm{~h}$. The absorbance was read at $\mathrm{OD}_{405}$, and the activity (units) was extrapolated from a standard curve.

\section{Statistical analysis}

All data were analyzed using SAS version 6.12 software and the results were recorded as average \pm standard deviation. The significance of the differences between groups was evaluated by analysis of variance, followed by a paired $t$ test. $P<0.05$ was considered statistically significant.

\section{Results}

Semi-quantitative RT-PCR analysis of CEA, UPA, UPAR, and PAI-1 mRNA expression

CEA is an important marker for gastroenteric tumors. Thereby, we used a high sensibility nested RT-PCR method to detect the expression of CEA in gastric cancer tissues with or without peritoneal metastasis. As expected, the results were all positive for CEA in the peritoneal metastatic lesions of seven peritoneal metastasis patients (Figure 1). Also, by naked eye observation of peritoneal metastasis patients, three cases showed CEA-positive expression in the nonperitoneal metastatic tissues. Among the 24 patients with nonperitoneal metastasis, 2 had CEA-positive expression in normal peritoneal tissues. No CEA expression was detected in the peritoneal mesothelial cell line HMrSV5. However, uPA, uPAR, and PAI-1could be expressed in HMrSV5 cells (Figure 2).

\section{uPA system protein expression in gastric cancer tissues} with or without peritoneal metastasis

A quantitative ELISA method was used to determinate the UPA, UPAR, and PAI-1 protein contents in peritoneal metastatic lesions and CEA-negative nonperitoneal metastatic tissues of 7 peritoneal metastasis patients, and CEA-negative normal peritoneal tissues of 24 nonperitoneal metastasis patients. The results (Table 1) indicated that there were no significant differences in uPA, UPAR, and PAI-1 expression in two types of peritoneal tissue of seven peritoneal metastasis patients. However, uPA, uPAR, and PAI-1 expression were significantly higher in peritoneal metastatic lesions than those normal peritoneal tissues of 24 nonperitoneal metastasis patients $(P<0.05)$.

\section{uPA activity detection}

We also detected uPA activity in peritoneal metastatic lesions and CEA-negative nonperitoneal metastatic tissues of 7 peritoneal metastasis patients, and CEAnegative normal peritoneal tissues of 24 nonperitoneal metastasis patients. The results indicated that no statistical discrepancy was observed in various different tissues (Table 2).

\section{Discussion}

Owing to its lack of specific clinical manifestations in the early stage of peritoneal metastasis, the optimal treatment opportunity has always been missed in gastric cancer patients. The occurrence of ascites, abdominal tumors, and intestinal obstructions indicates an advanced stage of gastric cancer. Therefore, the effective diagnosis of gastric cancer with peritoneal metastasis is still a challenge in clinics. Currently, the main diagnostic method for gastric cancer with peritoneal metastasis includes peritoneal lavage and cytological investigation $[18,19]$. However, positive results only indicate subclinical peritoneal metastasis because the peritoneal metastasis is also not emergent even if tumor cells are present in the peritoneal fluid. Thus, detection in peritoneal tissues seems to be more direct and accurate. Remarkably, 


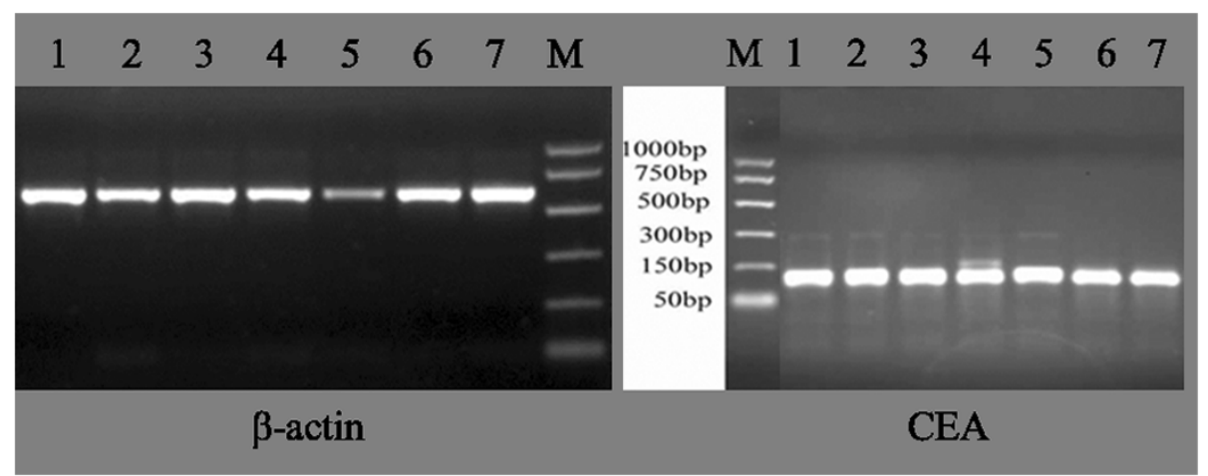

Figure 1 CEA mRNA expression in seven cases of gastric cancer with peritoneal metastasis. M: 1000 bp marker; Lanes 1, 2, 3, 4, 5, 6, and 7 indicated the seven peritoneal metastatic cases. $\beta$-actin was used for internal reference to normalize the expression of CEA. The amplification products were $131 \mathrm{bp}$ of CEA and $591 \mathrm{bp}$ of $\beta$-actin, respectively. CEA, carcinoembryonic antigen.

peritoneal tissues cover the whole peritoneal cavity, while tumor cell implantation is random, so direct detection of tumor cells in peritoneal tissues is very difficult. Molecular biologists believe that there are some molecular changes in self-tumor cells and their affected tissues, and these changes in tissues may be initiated before the tumor cells contact them [9]. Based on this concept, we investigated molecular changes in peritoneal tissues to explore the potential diagnosis of peritoneal metastasis.

CEA is a common tumor-associated antigen, and is accepted internationally as the gastroenteric tumor marker $[20,21]$. Therefore, we detected the expression of CEA in peritoneal tissues. Positive CEA-expression results indicate that tumor cells are present in peritoneal tissues. As expected, our results showed that CEA was expressed in all the peritoneal metastatic lesions of seven peritoneal metastasis patients. Interestingly, there were three patients with peritoneal metastasis in whom CEA was positively expressed in the nonperitoneal metastatic tissues and two patients with nonperitoneal metastasis who had positive CEA expression in normal peritoneal

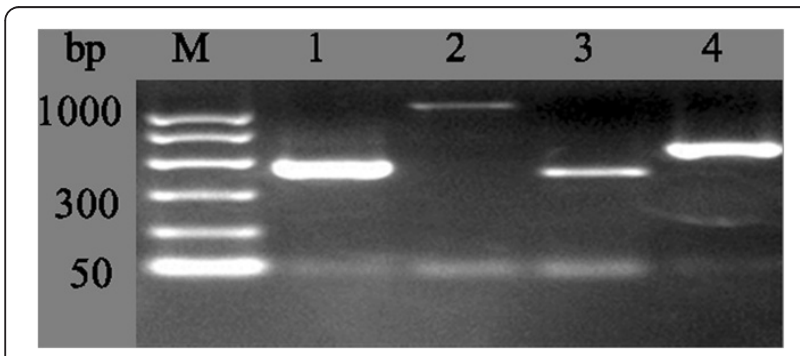

Figure 2 uPA system mRNA expression in HMrSV5 cell. M, 1000 bp marker; lane 1, uPA; lane 2, UPAR; lane 3, PAl-1; lane 4, $\beta$-actin. $\beta$-actin was used for internal reference. The amplification products were $474 \mathrm{bp}$ of UPA, $1046 \mathrm{bp}$ of UPAR, $409 \mathrm{bp}$ of PAl-1, and $591 \mathrm{bp}$ of $\beta$-actin, respectively. tissues. This suggests that these patients had a potential for developing peritoneal metastasis.

As it includes important proteolytic enzymes, the uPA system in tumor cells has been demonstrated to interact with the extracellular matrix to facilitate the microenvironment formation of metastases; thus, the uPA system may be involved in the process of peritoneal metastasis [22]. Expression of the uPA system is found to be increased in implanted tumor and host tissues [23,24]. The uPA system consists of the serine protease uPA, the glycolipid-anchored receptor, UPAR, and the serpin inhibitor, PAI-1, [25]. Therefore, we aimed to investigate comprehensively changes in these three factors in peritoneal tissues with or without metastasis.

The uPA system is widely distributed in various cells; our RT-PCR showed that UPA, UPAR, and PAI-1 could even be expressed in mesothelial cells. To avoid unspecific results, further quantitative ELISA was used to detect expression of the uPA system proteins. We found that UPA, UPAR, and PAI-1 protein contents were significantly higher in CEA-positive lesions or CEAnegative peritoneal tissues of peritoneal metastasis patients when compared with normal peritoneal tissues of nonperitoneal metastasis patients $(P<0.05)$. Notably, there may be greater clinical significance in the increased uPA system protein content in CEA-negative peritoneal tissues of peritoneal metastasis patients. This finding indicated that these CEA-negative peritoneal tissues might be in a state of subclinical peritoneal metastasis and that progression of this disease might lead to peritoneal metastasis. Although uPA system changes in peritoneal tissues have not yet definitely been demonstrated in tumor cells, the changes in peritoneal tissues at least provides a reference value for diagnosis of peritoneal metastasis [26]. Heiss et al. [27] find that UPAR could be considered as a dependent index for prediction of stomach cancer bone marrow micrometastasis compared with cytokeratin (CK18). In this study, uPAR 
Table 1 uPA system protein expression in gastric cancer tissues with or without peritoneal metastasis

\begin{tabular}{|c|c|c|c|c|c|}
\hline \multirow[t]{2}{*}{ Protein } & \multicolumn{2}{|c|}{ Peritoneal metastasis (7 cases) } & \multicolumn{3}{|c|}{ Nonperitoneal metastasis ( 24 cases) } \\
\hline & CEA(+) & CEA(-) & CEA(-) & & \\
\hline \multirow[t]{8}{*}{ UPA } & 3.312 & 2.488 & 0.408 & 0.784 & 0.640 \\
\hline & 3.088 & 1.664 & 0.280 & 0.632 & 0.488 \\
\hline & 2.952 & 0.648 & 0.672 & 0.664 & 0.224 \\
\hline & 0.712 & 0.504 & 0.280 & 0.800 & 0.424 \\
\hline & 0.520 & 0.488 & 0.440 & 0.656 & 0.328 \\
\hline & 0.480 & 0.128 & 0.440 & 0.256 & 0.384 \\
\hline & 0.376 & 1.440 & 0.512 & 0.440 & 0.848 \\
\hline & & & 0.312 & 0.464 & 0.168 \\
\hline \multirow[t]{8}{*}{ UPAR } & 3.664 & 4.936 & 1.432 & 0.345 & 1.034 \\
\hline & 2.720 & 2.304 & 0.640 & 1.256 & 0.532 \\
\hline & 2.744 & 2.192 & 1.536 & 0.239 & 0.479 \\
\hline & 1.432 & 1.808 & 0.704 & 0.671 & 0.561 \\
\hline & 0.912 & 1.280 & 0.792 & 0.845 & 0.390 \\
\hline & 1.184 & 0.480 & 0.272 & 0.432 & 0.633 \\
\hline & 1.064 & 2.728 & 1.280 & 0.467 & 0.291 \\
\hline & & & 1.120 & 0.968 & 0.776 \\
\hline \multirow[t]{8}{*}{ PAl-1 } & 1.511 & 4.204 & 0.568 & 3.665 & No detection \\
\hline & 3.872 & 1.725 & 0.262 & 1.426 & 0.071 \\
\hline & 2.782 & 0.876 & 0.488 & 3.598 & No detection \\
\hline & 0.369 & 0.745 & 0.662 & 0.488 & No detection \\
\hline & 1.315 & 3.023 & 0.894 & 0.127 & 0.289 \\
\hline & 1.041 & 0.262 & 0.963 & No detection & 0.195 \\
\hline & 1.181 & 0.977 & 0.041 & 0.329 & 0.395 \\
\hline & & & 0.085 & 0.316 & 0.382 \\
\hline
\end{tabular}

protein content was also significantly higher in CEAnegative peritoneal tissues of peritoneal metastasis patients than in CEA-negative peritoneal tissues of nonperitoneal metastasis patients $(P<0.05)$. In brief, we suggest that increased UPAR and PAI-1 expressions in

Table 2 uPA activity in gastric cancer tissues with or without peritoneal metastasis

\begin{tabular}{llllll}
\hline $\begin{array}{l}\text { Peritoneal metastasis } \\
\text { (7 cases) }\end{array}$ & & & \multicolumn{3}{l}{$\begin{array}{l}\text { Nonperitoneal metastasis } \\
\text { (24 cases) }\end{array}$} \\
\cline { 1 - 2 } \cline { 5 - 6 } CEA(+) & CEA(-) & & CEA(-) & & \\
\hline 19.936 & 16.536 & & 3.914 & 4.510 & 5.635 \\
0.846 & 3.091 & & 1.942 & 5.407 & 4.151 \\
1.417 & 8.725 & & 3.117 & 4.702 & 0.899 \\
2.352 & 16.170 & & 2.142 & 10.046 & 2.419 \\
2.820 & 4.799 & & 1.302 & 3.730 & 2.828 \\
2.123 & 3.310 & & 5.299 & 7.287 & 1.233 \\
6.066 & 6.533 & & 7.922 & 6.485 & 8.150 \\
& & 7.802 & 4.466 & 3.468 \\
\hline
\end{tabular}

peritoneal tissues of nonperitoneal metastasis patients may be regarded as a reference indicator for peritoneal metastasis.

By assay of the uPA activity in gastric cancer tissues and their extracellular matrix, Okusa et al. [28] report that the higher uPA activity is significantly associated with tumors with peritoneal metastases and tumors with deeper invasion into the gastric wall. uPA produced by stromal cells may regulate cancer cell invasion [29]. However, our results showed that there was no significant difference in UPA activity between different tissues. This may be attributed to the dynamic activity of uPA, which appears to be dependent on the particular cellular environments and states that it encounters [30].

\section{Conclusions}

Our study shows that uPA system expression is significantly higher in peritoneal tissues of peritoneal metastasis patients than in nonperitoneal metastasis patients. This expression difference may provide a reference for diagnosis of peritoneal metastasis. However, there are 
still some limitations in this study. The number of cases included in this study was rather small, mainly because few patients with peritoneal metastasis were admitted in our hospital between July 2010 and December 2010. We tried to remove the influence of this problem by including tissues (including omentum majus, pelveoperitoneum, and diaphragmatic peritoneum) in this study. Further study with higher numbers of subjects is still needed to obtain clearer and more convincing results.

\section{Abbreviations \\ CEA: Carcinoembryonic antigen; DMEM: Dulbecco's modified Eagle's medium; ELISA: Enzyme-linked immunosorbent assay; \\ GAPDH: Glyceraldehyde-3-phosphate dehydrogenase; PCR: Polymerase chain reaction; RT: Reverse transcriptase; RT-PCR: Reverse transcriptase polymerase chain reaction; UPA: Urokinase-type plasminogen activator; UPAR: Urokinase- type plasminogen activator receptor.}

\section{Competing interests}

The authors declare that they have no financial or nonfinancial competing interests.

\section{Authors' contributions}

YD and ZZ designed the study, and performed RT-PCR, ELISA, and activity detection with $\mathrm{HZ}$ and ZZhou. YD, MZ, and XW participated in the sequence alignment and drafted the manuscript. ZZ helped to conduct statistical analysis. All authors read and approved the final manuscript.

\section{Acknowledgements}

We gratefully acknowledge the following individuals: Xuehua Chen, who participated in the sequence alignment and helped in preparing the manuscript. We also acknowledge Yubao Ji, Yi Zhang, and Bin LV, who contributed to this study.

\section{Author details}

'Department of General Surgery, East Hospital, TongJi University School of Medicine, 150 Jimo Road, Shanghai 200120, China. ${ }^{2}$ Department of Gastroenterology, Ruijin Hospital, Shanghai Jiao Tong University School of Medicine, 197 Ruijin Road II, Shanghai 200025, China.

Received: 7 November 2012 Accepted: 19 August 2013

Published: 28 August 2013

\section{References}

1. Yang L: Incidence and mortality of gastric cancer in China. World J Gastroenterol 2006, 12:17

2. Yoo C, Noh S, Shin D, Choi S, Min J: Recurrence following curative resection for gastric carcinoma. British J Surg 2000, 87:236-242.

3. Wei Y, Tang CH, Kim Y, Robillard L, Zhang F, Kugler MC, Chapman HA: Urokinase receptors are required for a5 $\beta 1$ integrin-mediated signaling in tumor cells. J Biol Chem 2007, 282:3929.

4. Lee DH, Yang Y, Lee SJ, Kim KY, Koo TH, Shin SM, Song KS, Lee YH, Kim YJ, Lee JJ: Macrophage inhibitory cytokine-1 induces the invasiveness of gastric cancer cells by up-regulating the urokinase-type plasminogen activator system. Cancer Res 2003, 63:4648.

5. de Bock CE, Wang Y: Clinical significance of urokinase-type plasminogen activator receptor (UPAR) expression in cancer. Med Res Rev 2004, 24:13-39.

6. Dass K, Ahmad A, Azmi AS, Sarkar SH, Sarkar FH: Evolving role of uPA/uPAR system in human cancers. Canc Treat Rev 2008, 34:122-136.

7. Kwaan HC, McMahon B: The role of plasminogen-plasmin system in cancer. Cancer Treat Res 2009, 148:43-66.

8. Andreasen PA, Kjøller L, Christensen L, Duffy MJ: The urokinase-type plasminogen activator system in cancer metastasis: a review. Int J Cancer 1997, 72:1-22.

9. Liotta LA, Kohn EC: The microenvironment of the tumour-host interface. Nature 2001, 411:375-379.

10. Plebani M, Herszènyi L, Carraro $P$, De Paoli M, Roveroni G, Cardin R, Tulassay $Z$, Naccarato R, Farinati F: Urokinase-type plasminogen activator receptor in gastric cancer: tissue expression and prognostic role. Clin Exp Metastasis 1997, 15:418-426.

11. Taniguchi $K$, Yonemura $Y$, Nojima N, Hirono $Y$, Fushida S, Fujimura T, Miwa $\mathrm{K}$, Endo $\mathrm{Y}$, Yamamoto $\mathrm{H}$, Watanabe $\mathrm{H}$ : The relation between the growth patterns of gastric carcinoma and the expression of hepatocyte growth factor receptor (c-met), autocrine motility factor receptor, and urokinasetype plasminogen activator receptor. Cancer 1998, 82:2112-2122.

12. Lee KH, Bae SH, Lee JL, Hyun MS, Kim SH, Song SK, Kim HS: Relationship between urokinase-type plasminogen receptor, interleukin-8 gene expression and clinicopathological features in gastric cancer. Oncology 2004, 66:210-217

13. Kaneko T, Konno H, Baba M, Tanaka T, Nakamura S: Urokinase-type plasminogen activator expression correlates with tumor angiogenesis and poor outcome in gastric cancer. Cancer Sci 2003, 94:43-49.

14. Kita Y, Fukagawa T, Mimori K, Kosaka Y, Ishikawa K, Aikou T, Natsugoe S, Sasako M, Mori M: Expression of uPAR mRNA in peripheral blood is a favourite marker for metastasis in gastric cancer cases. Bri J Cancer 2008, 100:153-159.

15. Lee DH, Lee Y, Ryu J, Park SG, Cho S, Lee JJ, Choi C, Park BC: Identification of proteins differentially expressed in gastric cancer cells with high metastatic potential for invasion to lymph nodes. Mol Cells 2011, 31:583-571.

16. Zhang $L$, Zhao ZS, Ru GQ, Ma J: Correlative studies on uPA mRNA and UPAR mRNA expression with vascular endothelial growth factor, microvessel density, progression and survival time of patients with gastric cancer. World J Gastroenterol 2006, 12:3970.

17. Ito $H$, Yonemura $Y$, Fujita $H$, Tsuchihara K, Kawamura T, Nojima N, Fujimura T, Nose H, Endo Y, Sasaki T: Prognostic relevance of urokinase-type plasminogen activator (UPA) and plasminogen activator inhibitors PAIand PAI-2 in gastric cancer. Virchows Arch 1996, 427:487-496.

18. Fujimura T, Kinami S, Ninomiya I, Kitagawa H, Fushida S, Nishimura G, Kayahara M, Shimizu K, Ohta T, Miwa K: Diagnostic laparoscopy, serum CA125, and peritoneal metastasis in gastric cancer. Endoscopy 2002, 34:569-574.

19. Yonemura Y, Fujimura T, Ninomiya I, Kim BS, Bandou E, Sawa T, Kinoshita K, Endo Y, Sugiyama K, Sasaki T: Prediction of peritoneal micrometastasis by peritoneal lavaged cytology and reverse transcriptase-polymerase chain reaction for matrix metalloproteinase-7 mRNA. Clin Cancer Res 2001, 7:1647-1653.

20. Fan $B$, Xiong B: Investigation of serum tumor markers in the diagnosis of gastric cancer. Hepato-gastroenterol 2011, 58:239.

21. Ucar E, Semerci E, Ustun H, Yetim T, Huzmeli C, Gullu M: Prognostic value of preoperative CEA, CA 19-9, CA 72-4, and AFP levels in gastric cancer. Adv Ther 2008, 25:1075-1084

22. Holst-Hansen C, Johannessen B, Hoyer-Hansen G, Romer J, Ellis V, Brünner $\mathrm{N}$ : Urokinase-type plasminogen activation in three human breast cancer cell lines correlates with their in vitro invasiveness. Clin Exp Metastasis 1996, 14:297-307.

23. Huang S, New L, Pan Z, Han J, Nemerow GR: Urokinase plasminogen activator/urokinase-specific surface receptor expression and matrix invasion by breast cancer cells requires constitutive p38a mitogen-activated protein kinase activity. J Biol Chem 2000, 275:12266-12272.

24. Hsiao JK, Law B, Weissleder R, Tung CH: In-vivo imaging of tumor associated urokinase-type plasminogen activator activity. J Biomed Optics 2006, 11:034013.

25. Duffy M, Duggan C: The urokinase plasminogen activator system: a rich source of tumour markers for the individualised management of patients with cancer. Clin Biochem 2004, 37:541-548.

26. Rosenthal EL, Johnson TM, Allen ED, Apel IJ, Punturieri A, Weiss SJ: Role of the plasminogen activator and matrix metalloproteinase systems in epidermal growth factor-and scatter factor-stimulated invasion of carcinoma cells. Cancer Res 1998, 58:5221.

27. Heiss MM, Simon EH, Beyer BCM, Gruetzner KU, Tarabichi A, Babic R, Schildberg FW, Allgayer $\mathrm{H}$ : Minimal residual disease in gastric cancer: evidence of an independent prognostic relevance of urokinase receptor expression by disseminated tumor cells in the bone marrow. J Clin Oncol 2002, 20:2005-2016

28. Okusa Y, Ichikura T, Mochizuki H: Prognostic impact of stromal cellderived urokinase-type plasminogen activator in gastric carcinoma. Cancer 1999, 85:1033-1038. 
29. Bogenrieder T, Herlyn M: Axis of evil: molecular mechanisms of cancer metastasis. Oncogene 2003, 22:6524-6536.

30. Saldanha RG, Molloy MP, Bdeir K, Cines DB, Song X, Uitto PM, Weinreb PH, Violette SM, Baker MS: Proteomic identification of lynchpin urokinase plasminogen activator receptor protein interactions associated with epithelial cancer malignancy. J Proteome Res 2007, 6:1016-1028.

doi:10.1186/2047-783X-18-28

Cite this article as: Ding et al: Clinical significance of the uPA system in gastric cancer with peritoneal metastasis. European Journal of Medical

Research 2013 18:28.

\section{Submit your next manuscript to BioMed Central and take full advantage of:}

- Convenient online submission

- Thorough peer review

- No space constraints or color figure charges

- Immediate publication on acceptance

- Inclusion in PubMed, CAS, Scopus and Google Scholar

- Research which is freely available for redistribution 